\title{
Forgery Detection Beef with Mice Meat (Mus musculus) in Meatballs Using Real-Time Polymerase Chain Reaction (Real-Time PCR) Primer Specific for a Target Mitochondrial DNA ND-1 Gene
}

\author{
Tri Joko Raharjo ${ }^{1,2,}$, Gilang Aji Pratama ${ }^{2}$, Irma Nuryanti ${ }^{1,3}$, and Rarastoeti Pratiwi ${ }^{2,4}$ \\ ${ }^{1}$ Department of Chemistry, Faculty of Mathematics and Natural Sciences, Universitas Gadjah Mada, \\ Sekip Utara, Yogyakarta 55281, Indonesia \\ ${ }^{2}$ Biotechnology Study Program, Graduated School, Universitas Gadjah Mada, Yogyakarta 55281, Indonesia \\ ${ }^{3}$ Dexa Laboratories of Biomolecular Sciences, Cikarang, Bekasi 17530, West Java, Indonesia \\ ${ }^{4}$ Faculty of Biology, Universitas Gadjah Mada, Sekip Utara, Yogyakarta 55281, Indonesia
}

\section{* Corresponding author: \\ email:trijr_mipa@ugm.ac.id}

Received: August 16, 2017

Accepted: February 1, 2018

DOI: $10.22146 / \mathrm{ijc} .27542$

\begin{abstract}
The expensive beef price have encouraged counterfeiting beef on processed food products such as meatballs. Mice meat is frequently reported used for adulteration of beef. The accurate method is needed to ensure the supervision of food safety. This study reports the use of DNA testing to detect the presence of mice meat in meatballs with realtime PCR primer specific. PCR primers designed based on the ND-1 gene of mice mitochondrial DNA with the sequence are 5'-CGGCATCCTACAACCATTTGC-3' and 5'-CGGCTCGTAAAGCTCCGAA-3', respectively, target 294 bp DNA fragment. The real-time PCR can specifically detect the presence of the mice meat in a meatball with no detection of the presence of beef, mutton, chicken, pork, and horsemeat. The method showed good precision shown by the CV of repeatability test at 2\%, much lower than the requirement of $<25 \%$. Real-time PCR was able to deliver positive results for as low as $0.5 \mathrm{ng}$ DNA template, equivalent to 0.08 copies of genome DNA of mice equal to 80-150 copies of mtDNA. By using standard phenol-chloroform DNA isolation technique, this method is able to detect contamination of mice meat in meatball up to $1 \%$. Three commercial meatballs are confirmed to be contaminated by mice meat using the method.
\end{abstract}

Keywords: mice; meatball; real-time PCR; ND-1; mitochondrial DNA

\section{- INTRODUCTION}

The increasing need for beef in processed food products that are not mitigated by the availability of sufficient supplies has occurred in Indonesia. This fact leads to counterfeiting of beef used in processed food products. One of the processed meat-based food that are risky to be included is meatballs. The meatball processing involves other ingredients, so the final product has changed the texture, smell, and taste. The meat that is often used for counterfeiting beef is pork that has lower economic value. However, counterfeiting beef with other meat including mice meat has been started to be reported [1]. Mice are used because the cultivation process is easy and has a cleaner impression so more acceptable by the meatball maker. This forgery is of course very detrimental to the consumer because in addition to food safety but also related to halal food, considering the meat of mice syar'i not allowed to be consumed by Muslims. A reliable method to detect the adulteration of meatball by mice meat is essential to monitor and law enforcement.

DNA testing offers an advantage to be applied to the falsification test of meat in the diet. It is because the DNA test detects the species directly, besides DNA is also relatively stable to the cooking process of food [2]. Polymerase Chain Reaction (PCR) technique to amplify the DNA specifically that could be applied to identify the presence of a species by amplification of its DNA 
specifically. There are several types of PCR including PCR-RAPD, PCR-RFLP and PCR primer specific and real-time PCR. These techniques have been reported the presence of porcine in food including PCR primer specific [3-4]; PCR-RFLP [5-6], PCR-RAPD [7-8], real-time PCR [9-10]. In case of detection of mice, only a few work has been reported. Steube et al. [11] have reported the use of conventional PCR to detect murine and related species. Meanwhile, real-time PCR using TaqMan probe has been established including single identification as well as multiple species identification $[4,12]$.

Conventional PCR specific primer and real-time PCR nonspecific dye seem to be most frequently reported as a method to identify species since both offer simple, quick and cheap advantages. Both methods required the specific target of DNA which has a high variation of the sequence to be specifically amplified. Mitochondrial DNA (mtDNA) meet the criteria of high variety in sequence among species due to its high rate mutation of mtDNA. The mtDNA also offer another benefit in term of its high copy number which could reach as much as 1000 copies per cell meaning only a little amount of sample needed lead to the advantage in term of sensitivity. mtDNA contains several genes, and among the gene, the sequence of CytB gen and D-loop are very famous for designing primer or the probe for PCR and real-time PCR $[4,12]$. However, other genes present in mtDNA remain a challenge to be studied as a target for PCR as well as realtime PCR.

The primers for conventional PCR to specifically detect mice in meatball have been designing based on the sequence of 12SrRNA gene, ND-1 gene as well D-loop of mice (Mus musculus) mtDNA. Among the designed primer, a primers pair targeted ND-1 gene amplified specifically ND-1 gene of mice but no amplification of other species. This ND-1 primer also shows good precision and limit of detection in the detection of mice in meatball [13]. This study reports the performance test of published the ND-1 primer for real-time PCR. As generally known, real-time PCR offers an advantage in term of faster and real-time method as well as applicable for the quantitative purpose. Real-time PCR need a shorter target of amplification, usually less than $100 \mathrm{bp}$ and need to be designed specifically. Although the size of PCR results with ND-1 primers is greater than $100 \mathrm{bp}$, but previous studies have shown that more than $100 \mathrm{bp}$ real-time PCR targets are still yielding good results. The existing primer of conventional PCR such as ND-1 primer is interested to be used as a primer for real-time PCR. It will shorten the development method of realtime PCR.

\section{- EXPERIMENTAL SECTION}

\section{Materials}

The forward primer (5'-CGGCATCCTACAACC ATTTGC-3') and reverse primer (5'-CGGCTCGTAAA GCTCCGAA-3') were synthesized by IDT Singapore according to design that reported previously [13]. The positive control of mice meatball and negative control beef meatball was prepared in the laboratory. For specificity test, several types of meatball: chicken meatball, pork meatball, horseflesh meatball and goat meat were also prepared in the laboratory. Beef meatball with various content of mice meat $(1,2,5,10,25,50$ and $75 \%(\mathrm{w} / \mathrm{w}))$ were prepared to test the sensitivity of the methods. The commercial meatball was purchased from several local food stalls in Yogyakarta.

\section{Procedure}

\section{DNA isolation}

DNA isolation using a sample of meatballs in the form of grinding powder. The isolation was performed based on Sambrook DNA isolation method with minor modifications [14]. One hundred mg of meatball powder was mixed with $1 \mathrm{~mL}$ lysis buffer $(50 \mathrm{mM}$ Tris- $\mathrm{HCl} \mathrm{pH}$ 8, $100 \mathrm{mM}$ EDTA, $100 \mathrm{mM} \mathrm{NaCl}$ and $1 \%$ SDS). The mixture is added to $30 \mathrm{~mL}$ solution of proteinase $\mathrm{K}$ then incubated at $37^{\circ} \mathrm{C}$ for $2 \mathrm{~h}$. The extraction of DNA was started with homogenization using vortex for $3 \mathrm{~min}$, followed by addition of the same volume of phenolCIAA solution, shook for $30 \mathrm{~min}$ then centrifuged for $5 \mathrm{~min}$ at $12,000 \mathrm{x}$ g at $4{ }^{\circ} \mathrm{C}$. The extraction was repeated to the supernatant of the first extraction. The final supernatant was added with $2.5 \mathrm{M}$ sodium acetate $\mathrm{pH}$ 5.2 as much as $0.1 \mathrm{x}$ volume of supernatant and cold ethanol absolute as much as $2.5 \mathrm{x}$ volume of supernatant 
shake then centrifuged for $5 \mathrm{~min}$ at $12,000 \mathrm{x} \mathrm{g}$ at a temperature of $4{ }^{\circ} \mathrm{C}$. The isolated DNA was washed with $70 \%$ ethanol and finally dissolved in $100 \mu \mathrm{L}$ of TE buffer. To check purity and to determine the DNA, $10 \mu \mathrm{L}$ of DNA solution was dissolved ten times, and the absorbance was measured at 260 and $280 \mathrm{~nm}$. A part of DNA solution was also subjected to gel electrophoresis analysis using a $2 \%$ agarose gel at $100 \mathrm{~V}$ for $50 \mathrm{~min}$ and employed a DNA ladder $100 \mathrm{bp}$ as standard.

\section{Real-time PCR}

The real-time PCR reaction was prepared by mixing $50 \mathrm{ng}$ of isolated with $10 \mu \mathrm{L}$ EvaGreen, $1 \mu \mathrm{L}$ of each forward primer and reverse primer $(\mu \mathrm{M})$, and DNAse free water to a volume of $20 \mu \mathrm{L}$. The thermal cycler process was performed with the help of Biorad CFX-96 machine using this following condition: pre-denaturation at temperatures of $95^{\circ} \mathrm{C}$ for $5 \mathrm{~min}$, followed by 30 cycles of denaturation at a temperature of $95{ }^{\circ} \mathrm{C}$ for $1 \mathrm{~min}$, annealing at $55^{\circ} \mathrm{C}$ for $1 \mathrm{~min}$ and extension at $72{ }^{\circ} \mathrm{C}$ for $1 \mathrm{~min}$. The melt curve analysis was performed from 65$95{ }^{\circ} \mathrm{C}$ using gradual increase of temperature at $0.5^{\circ} \mathrm{C} / 2$ min. The monitoring of amplification, as well as melt curve analysis, was at $\lambda_{\mathrm{abs}}=497 \mathrm{~nm}$ and $\lambda_{\mathrm{em}}=520 \mathrm{~nm}$.

\section{Method performance confirmation}

The specificity of the method DNA was confirmed by performing real-time PCR method under method as described before to the sample of DNA isolated from meatball of mice (positive control) and beef meatball (negative control). Further specificity investigation also carried out using DNA isolated from the meat of other species of meat including goat, horse, pig, and chickens. The method concludes to be specific if real-time PCR gives a positive result only to the DNA sample of mice meatball.

The repeatability test was implemented to assess the precision of the method. The isolation of DNA out of mice meatball, as well as real-time PCR, was performed to 10 independent mice meatball. Since the real-time PCR is a semi-quantitative method; the precision was concluded if the method was able to give consistent positive results for mice meatball. The quantitative precision was determined based on the coefficient of variation (CV) of the Cq value of real-time PCR and compare with the maximum acceptance criteria.

Two approaches were done in the determination of the method cut off. Meatball contamination cut off was determined by carrying out the test targeted to a series of beef meatballs with various concentration of mice meat contamination $(1,2,5,10,25$ and $50 \%(w / w))$. The lowest level of mice contamination in meatballs which still give positive result obtained as the cut off of the methods. The cut off in term of minimum copies of DNA which give positive result was determined using serial dilution of isolated DNA from mice meatball as a template of real-time PCR. The range of amount DNA used were 50000, 5000, 500, 50 and 5 pg. The lowest amount of DNA which gave a positive result with good precision convert to the number of copies of the DNA and declare as minimum copies of DNA still able to be amplified by the method.

\section{Application of the method to commercial meatball}

Ten commercial meatball samples were purchased randomly from some food stalls, the traditional market as well as a supermarket in Yogyakarta. DNA of each meatball sample was isolated and used as real-time PCR template using condition as described early. Laboratory prepared mice meatball and beef meatball were used as a control.

\section{- RESULTS AND DISCUSSION}

Some factors that affect the success of PCR amplification are the quality of the DNA template and the optimum annealing temperature. Isolation DNA from meatball using phenol-chloroform extraction has been reported as a good strategy. Moreover, the target amplification is mtDNA which present in high copy number in every cell would have helped the PCR amplification. In this research, the worst DNA isolation result is $100 \mathrm{ng} / \mu \mathrm{L}$ which much higher than the need for real-time PCR template which requires $50 \mathrm{ng}$ for genomic DNA and even much low amount for mtDNA due to high copies of mtDNA in each cell. In the case of annealing temperature, since the real-time PCR uses a primer that has been reported successfully used for conventional PCR, the reaction condition of PCR 

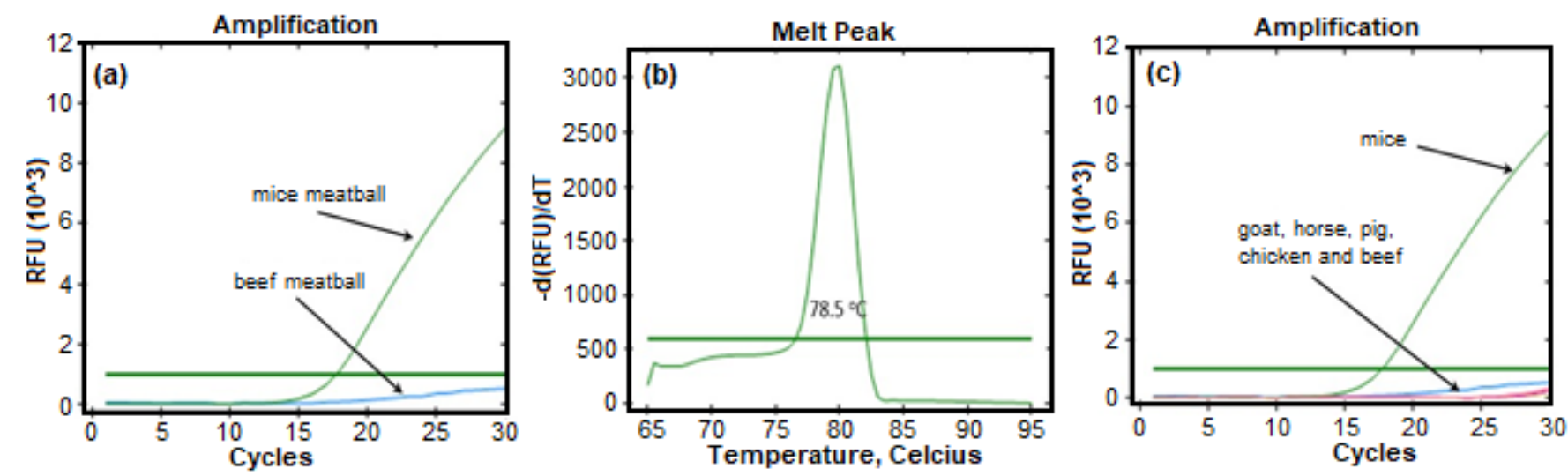

Fig 1. Real-time PCR amplification chart of specificity test of (a) positive control (mice meatball) and negative control (beef meatball); (b) melt curve of mice meatball amplification product; and (c) specificity of real-time PCR against other species

including annealing temperature could be used as starting point of real-time PCR optimization. The result shows that optimum condition of conventional PCR, $95^{\circ} \mathrm{C}$ for 1 min denaturation, $55^{\circ} \mathrm{C}$ for $1 \mathrm{~min}$ annealing, $72^{\circ} \mathrm{C}$ for 1 min extension, give a good performance of real-time PCR. Therefore, this condition was used for the entire research and recommended as a condition for a real-time PCR testing method to detect mice in meatball using real-time PCR using ND-1 primer.

\section{Specificity of Real-Time PCR ND-1 Primer to Mice in Meatball}

Fig. 1 shows real-time PCR result under the optimum condition to investigate the specificity of the method. Amplification chart in Fig. 1(a) show increasing fluorescent of amplification of DNA isolated from mice meatball while there is not increasing of fluorescent DNA of beef meatball mean that the real-time PCR successfully amplify mice DNA in meatball specifically. Further confirmation of other species such as goat, horse, pig, and chicken gave no amplification as shown in Fig. 1(c). These results confirm the specificity of real-time PCR with ND1 primers that can not only be used to identify forgery or rat contamination in the meatballs but at the same time be used for the authentication of meat used in meatballs.

In non-specific dye real-time PCR, the positive result is not always related to correct amplification. Mispriming, as well as primer-dimer reaction, could also lead to increasing of fluorescent. The ND-1 primer has been reported producing single DNA fragment using conventional PCR. Melt curve analysis of real-time PCR product indicated that gradually increasing the real-time PCR product resulting denaturation of the amplicon. Fig. 1(c) show only temperature, $78.5^{\circ} \mathrm{C}$ appear to be the melting temperature Tm of the PCR product, conclude that real-time PCR only produces a single amplicon product, which is same with the result of conventional PCR using same primer and PCR condition.

According to the design information, the ND-1 primers were able to amplify a $294 \mathrm{bp}$, much longer than common real-time PCR primer which usually targeted less than 100 bp. Fig. 1(a) confirm that the $294 \mathrm{bp}$ fragments still feasible to be amplification target of realtime PCR, as shown by the fact that up to 30 cycles, the amplification still at logarithmic phase. Given the template is mtDNA which present in high copies and the amount of total DNA use as template source is standard $50 \mathrm{ng}$, the result is very promising in term of application of PCR designed primer for the real-time PCR application.

\section{Precession of the Methods}

According to Broeders et al. [15], the precision of real-time PCR method could be decided based on the RSD of the repeatability or reproducibility test. The Cq (cycle of quantification) is the parameter to be observed. The amplification chart of 10 replication of the same sample of the mice meatball was figured in Fig. 2(a) with 

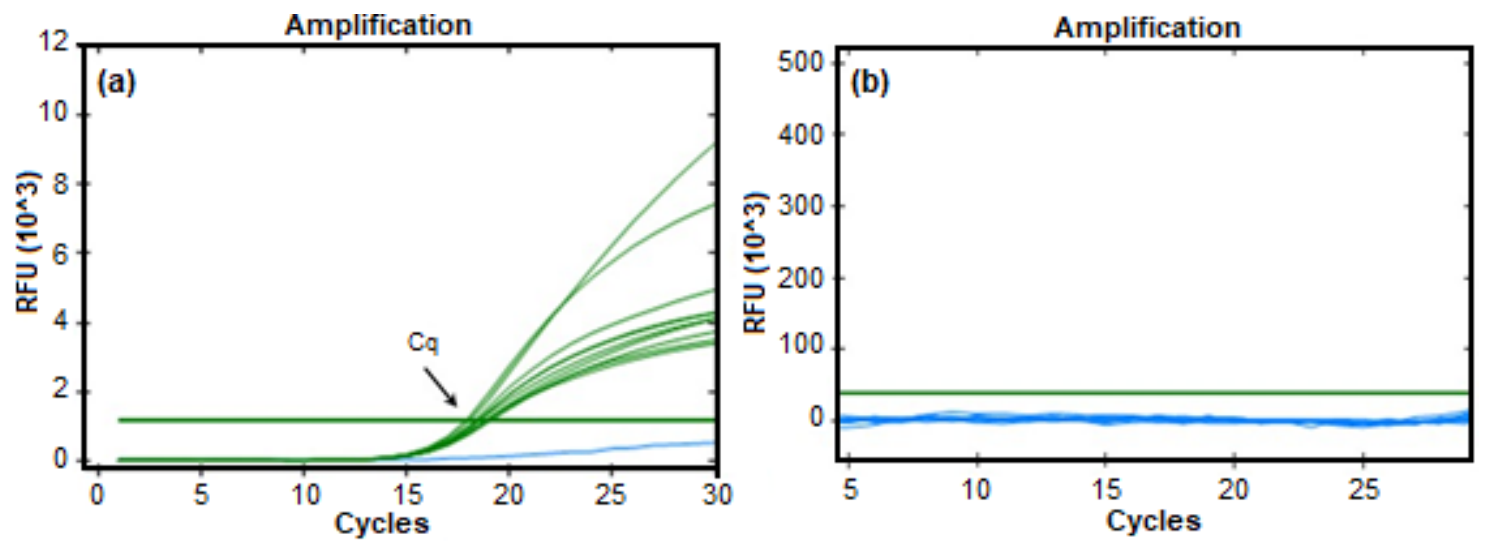

Fig 2. The result of ten replications of real-time PCR of (a) mice meatball and (b) beef meatball
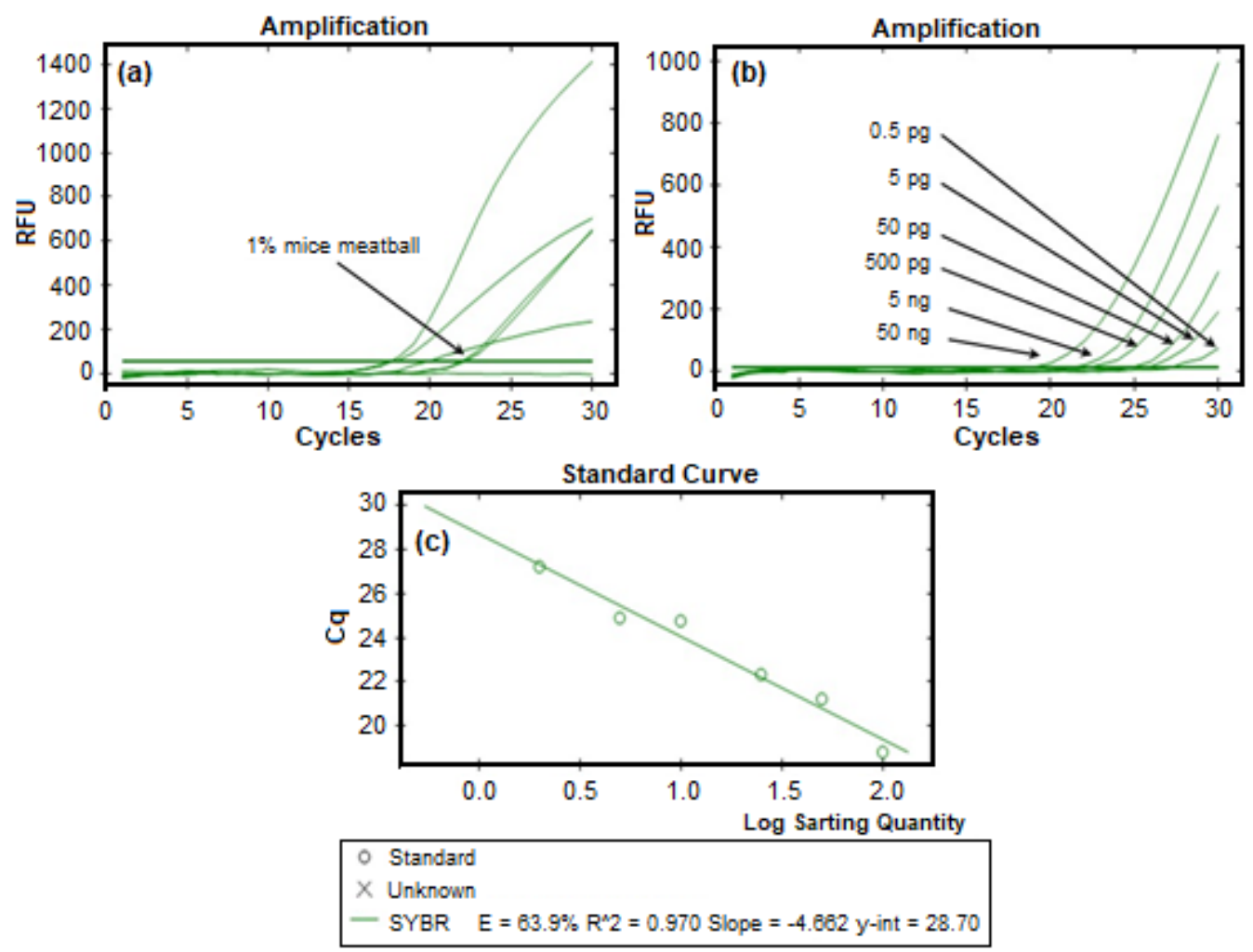

Fig 3. Amplification chart of real-time PCR in the determination of cut-off: (a) meatball with various content of mice meat; (b) different amount of DNA template; (c) linearity graph of amplification against the amount of template

Cq value was range between 17.99 to 19.00 with an average of 18.45 . The $\mathrm{CV}$ of the Cq value was $2 \%$, much lower than accepted criteria which are $<25 \%$. The good precision real-time PCR also requires no false positive nor false negative result [16]. Fig. 2(a) confirm that all the mice meatball sample gave a positive result, while the beef meatball as negative control give no amplification meaning there was no false positive. It means that the method has good precision. Since the replication cover whole step from DNA isolation to real-time PCR, therefore the good precision reflect not only the realtime PCR measurement but also the entire method.

\section{The Detection Limit of the Method}

What the main advantage of real-time PCR compares to conventional PCR is the quantitative application possibility. In real-time PCR, the success of 
Table 1. Real-time PCR test result of commercial meatball sample

\begin{tabular}{cccc}
\hline \multirow{2}{*}{ No } & Meatball sample & \multicolumn{2}{c}{ Test Result } \\
\cline { 3 - 4 } & & Qualitative & Cq value \\
\hline 1 & Meatball 1 & positive & 26.09 \\
2 & Meatball 2 & positive & 28.07 \\
3 & Meatball 3 & negative & \\
4 & Stahll 1 & negative & \\
5 & Stahll 2 & negative & \\
6 & Stahll 3 & negative & \\
7 & Stahll 4 & negative & \\
8 & Stahll 5 & negative & \\
9 & Stahll 6 & negative & \\
10 & Stahll 7 & positive & 27.34 \\
\hline
\end{tabular}

DNA isolation is a key factor. However, nowadays, the protocol or kit to isolate DNA from food sample including meatball is already established. It observes limit detection is valuable to assess the performance of the method. Two approaches were employed to calculate the limit of detection, limit detection of mice in meatball and limit detection of minimal copy number of DNA need to give detectable amplification process.

Data on Fig. 3(b) show that the minimum amount of template that still gives amplification with $\mathrm{Ct}$ (cycle threshold) less than 30 is $0.5 \mathrm{pg}$. The linearity of $\mathrm{Ct}$ to the amount of the template is also acceptable, as shown in Fig. $3(\mathrm{c})$, mean that the method is reliable for quantitative analysis. Based on the size of the diploid mice (Mus musculus) genome, which was approximately $2.64 \mathrm{~Gb}$ [17], 0.5 pg of mice total DNA was equivalent 0.088 copy of genomic DNA. Since the average of mtDNA content in mammalian meat tissue is approximately $1000-2000$ copies per cell or genome, meaning that the copy of mtDNA template that still gives positive amplification is in order of 80-150 copies much lower than conventional PCR that needs at least 10000 copies of the template to give detectable amplicon. The detection limit of the presence of mice in meatball is $1 \%$, based on the amplification chart as shown in Fig. 3(a). The Ct value of $5 \%$ contamination almost same with $1 \%$ contamination [16]. It seems that analysis of meatball sample especially at low concentration gives poor precision. It could be due to the meatball sample which is not homogeneous.
Therefore, representative sampling method should be employed at routine analysis using the method. This result is much higher compared to other latest study in other meat species which reported up to $0.01 \%$ detection limit [18] or up to $0.2 \%$ for meat-based food [19]. However, the value of $1 \%$ is more than enough since forgery usually involved high concentration if not the $100 \%$ adulteration.

\section{Contamination of Mice in the Commercial Meatball}

The method was applied to check the presence of mice meat contamination in commercial meatball from the market and food stall. The summarized data in Table 1 show that three meatball samples were positive contaminated by mice meat, two were meatball purchased from the supermarket while only one sample is coming from a food stall. However, the Cq value of the contaminated meatball were more than 25 , and if compared to Fig. 3(b), the amount of mice DNA present in the sample is very low, ranging from $800-1500$ copies of mtDNA equivalent to 0.8 copy of genomic DNA. The low amount of mice DNA lead to the conclusion that the meatball sample was contaminated but not adulterated, since the counterfeiting will result in high contents of mice DNA confirmed by lower Ct value, less than 20 . This justification is not difficult to be done using conventional PCR while showing the strength of this method compares to the existing methods.

\section{- CONCLUSION}

The real-time PCR primers 5'-CGGCATCCTACA ACCATTTGC-3' and 5'-CGGCTCGTAAAGCTCCGA A-3' targeted ND-1 gene of mtDNA show good specificity to detect the presence of mice in the meatballs and do not detect the presence of beef, mutton, chicken, pork, and horsemeat. The method also showed good with RSD in repeatability test of $\mathrm{Ct}$ value at $2 \%$, much lower than the maximum requirement of $25 \%$. Real-time PCR amplification was still able to deliver positive results for the number of total $0.5 \mathrm{ng}$ DNA template which is equivalent to 0 to $80-150$ copies of mice mtDNA much lower than conventional PCR that usually needs 10.000 copies. This method is also able to detect 
contamination of mice meat in meatball up to $1 \%$. Three commercial meatballs confirmed contaminated by mice meat using the method.

\section{- REFERENCES}

[1] Ruru, N., 2017, Positif mengandung tikus, petugas ambil ulang sampel daging bakso, http://kaltim.tribun news.com/2017/11/15/positif-mengandung-tikus-petu gas-ambil-ulang-sampel-daging-bakso, accessed on 27 January 2017.

[2] Rahmati, S., Julkapli, N.M., Yehye, W.A., and Basirun, W.J., 2016, Identification of meat origin in food products A review, Food Control, 68, 379-390.

[3] Karabasanavar, N.S., Singh, S.P., Kumar, D., and Shebannavar, S.N., 2014, Detection of pork adulteration by highly-specific PCR assay of mitochondrial D-loop, Food Chem., 145, 530-534.

[4] Ali, M.E., Razzak, M.A., Hamid, S.B., Rahman, M.M., Amin, M.A., Rashid, N.R., and Asing, 2015, Multiplex PCR assay for the detection of five meat species forbidden in Islamic foods, Food Chem., 177, 214-224.

[5] Ali, M.E., Hashim, U., Mustafa, S., and Che Man, Y.B., 2011, Swine-specific PCR-RFLP assay targeting mitochondrial cytochrome $b$ gene for semiquantitative detection of pork in commercial meat product, Food Anal. Methods, 5 (3), 613-623.

[6] Raharjo, T.J., Cahyaningtyas, W., Surajiman, Istini, and Pranowo, D., 2012, Validation of PCR-RFLP testing method to detect porcine contamination in chicken nugget, Indones. J. Chem., 12 (3), 302-307.

[7] Farouk, A.E., Batcha, M.F., Greiner, R., Salleh, H.M., Salleh, M.R., and Sirajudin, A.R., 2006, The use of a molecular technique for the detection of porcine ingredients in the Malaysian food market, Saudi Med. J., 27 (9), 1397-1400.

[8] Cunha, J.T., Ribeiro, T.I.B., Rocha, J.B., Nunes, J., Teixeira, J.A., and Domingues, L., 2016, RAPD and SCAR markers as potential tools for detection of milk origin in dairy products: Adulterant sheep breeds in Serra da Estrela cheese production, Food Chem., 211, 631-636.
[9] Rahmawati, Sismindari, Raharjo, T.J., Sudjadi, and Rohman, A., 2016, Analysis of pork contamination in Abon using mitochondrial D-Loop22 primers using real-time polymerase chain reaction method, Int. Food Res. J., 23 (1), 370-374.

[10] Maryam, S., Sismindari, S., Raharjo, T.J., Sudjadi, and Rohman, A., 2016, Determination of porcine contamination in laboratory prepared dendeng using mitochondrial d-loop and cyt b gene primers by real-time polymerase chain reaction, Int. J. Food Prop., 19 (1), 187-195.

[11] Steube, K.G., Koelz, A.L., and Drexler, H.G., 2008, Identification and verification of rodent cell lines by polymerase chain reaction, Cytotechnology, 56 (1), 49-56.

[12] Fang, X., and Zhang, C., 2016, Detection of adulterated murine components in meat products by TaqMan $\odot$ real-time PCR, Food Chem., 192, 485490.

[13] Nuryanti, I., Swasono, R.T, and Raharjo, T.J., 2014, Uji Spesifisitas Metode Deteksi Cemaran Daging Tikus Dalam Bakso Sapi Menggunakan Teknik Polymerase Chain Reaction (PCR) Primer Spesifik Berdasarkan Urutan DNA Mitokondria, Thesis, Department of Chemistry, Universitas Gadjah Mada, Yogyakarta.

[14] Sambrook, J., Fritsch, E.F., and Maniatis, T., 1989, Molecular Cloning: A Laboratory Manual, Cold Spring Harbor, N.Y., Cold Spring Harbor Laboratory Press, New York.

[15] Broeders, S., Huber, I., Grohmann, L., Berben, G., Taverniers, I., Mazzara, M., Roosens, N., and Morisset, D., 2014, Review: Guidelines for validation of qualitative real-time PCR methods, Trends Food Sci. Technol., 37 (2), 115-126.

[16] Pratama, G.A., Raharjo, T.J., and Pratiwi, R., 2017, Deteksi Kontaminan Daging Mencit (Mus musculus) Pada Bakso Sapi Menggunakan Metode Real-time Polymerase Chain Reaction (RT-PCR), Thesis, Biotechnology Study Program, Universitas Gadjah Mada, Yogyakarta.

[17] Guénet, J.L., 2005, The mouse genome, Genome Res., 15 (12), 1729-1740. 
[18] Xu, R., Wei, S., Zhou, G., Ren, J., Liu, Z., Tang, S., Cheung, P.C.K., and Wu, X., 2018, Multiplex TaqMan locked nucleic acid real-time PCR for the differential identification of various meat and meat products, Meat Sci., 137, 41-46.
[19] Prusakova, O.V., Glukhova, X.A., Afanas'eva, G.V., Trizna, Y.A., Nazarova, L.F., and Beletsky, I.P., 2018, A simple and sensitive two-tube multiplex PCR assay for simultaneous detection of ten meat species, Meat Sci., 137, 34-40. 